\title{
Reputation reform strategies in local government: Investigating Denmark and Norway
}

\author{
Local Government Studies
}

\begin{abstract}
This article investigates reputation reform in Norwegian and Danish local government and whether they have the same strategy content depending on the degree of administrative involvement and municipality size. Political and administrative actors are likely to cultivate different types of reputation strategies (place or organisational reputation), which explicitly embrace the potentially diverging interests cultivated by the two types of actors. We use a comparative design and quantitative method with an empirical ambition to explore local government reputation strategies in two national contexts. We find that local government responses to reputation reform depend on the size of the municipality and the type of actors involved; the larger the municipality, the more the administration is involved. And the more that administrative actors are involved, the more the strategies target organisational reputation. The country-specific factors do not appear to be the most important determinants for reputation reform strategies.
\end{abstract}

\section{KEYWORDS}

Local government, reputation, motivation, local government size, comparative

\section{Word count:}




\section{Introduction}

While reputation activities originated in the private sector, they have also become very popular in the public sector over the last 15 years. Even bodies of local government have undertaken reputation reform. Local governments in Europe are currently marked by high reform activity (Bouckaert and Kuhlmann 2016), albeit with scarce knowledge about the impact that decentralised reform has on the local governments involved (Kuhlmann and Wayenberg 2016). Reform outcomes are assumed to differ between countries (Bouckaert and Kuhlmann 2016). Judging from extensive media coverage, the Scandinavian region seems to have a particular 'reputation reform eagerness' compared to the rest of Europe, and this article explores reputation reform in the Scandinavian context.

Local government reforms may have different motivations and focuses. In a neo-institutional perspective, the focus is on the tendency of organisations to copy one another and to use the same templates in such reform practises, both across and within countries. Organisations are held to capture trends and reforms to demonstrate that they are 'up to date' and to demonstrate this in a similar way and that the overall organisational changes become uniform in character over time (DiMaggio and Powell 1991).

Conversely, rationally oriented perspectives are more preoccupied with differences in reform outcomes, as they focus on intentional aims, strategies, and group interests. In his work with 
reputation in public agencies, Carpenter $(2001,2010)$ has argued in a rational line. He claims that actors have interests and influence in reputation strategies. From this follows that reputation strategies may have differentiated characteristics. In this perspective, the overall goal for a reputation-conscious public organisation is to ensure fundamental organisational interests. Rather than pursuing legitimacy through imitation and adaptation to institutional pressure resulting in conformity, the main purpose is to identify and communicate the uniqueness of the organisation to ensure autonomy (Carpenter and Krause 2012). For a public organisation, it is therefore especially important that actors behave in a way that does not raise questions regarding its autonomy but rather protects and/or enhances it vis-à-vis national political interference and the like.

Inspired by the reasoning in the rational perspective forwarded by Carpenter, this article aims to explore the relevance of agency (i.e. a purposeful way of managing reputation as opposed to imitation) and to explore how bodies of local government pursue reputation reforms in the Scandinavian context. To pursue this ambition, the article departs from a comparative approach, comparing Norway and Denmark by means of a quantitative dataset. Can conditions be identified that prompt local governments to make different choices? Do political and administrative actors pursue the same type of reputation strategies? Do local governments in Norway and Denmark pursue different reputation strategies? In answering these questions, the article responds to a recent call for research identifying the crucial conditions for when 
and how organisations choose reputation strategies in a systematic, comparative research design (Wæraas, Bjørnå, and Moldenæs 2014, 1301).

This article positions itself between two strands of Scandinavian research regarding local government reputation management. On the one hand, we examine the response of local governments to a strategy originating in the private sector in line with contributions that have theorised the distinctiveness of public sector organisations and the challenges that reputation management poses to that sector (Luoma-aho 2007; Wæraas and Byrkjeflot 2012; Frandsen, Johansen, and Salomonsen 2016). This 'distinctiveness' has mainly been dealt with in organisational terms. On the other hand, we will investigate the role and influence of major local government actors in line with contributions taking a more political, actor-oriented approach and investigate how local governments within the Scandinavian context perform reputation management (Bjørnå 2014, 2016; Salomonsen and Nielsen 2015).

By utilising a comparative research design, we expect the administrative power, the size (population) of the municipality, and the differences in political and administrative motives to explain the variation in the choice of reputation strategies among local governments. The contrasting motivations of politicians and administrations is a persistent issue in the study of policy processes (Christensen et al. 2002; Jacobsen 1960). This article investigates reputation reform management as a strategy that political and administrative actors potentially pursue differently. We assume that politicians are eager to present themselves as innovators and developers (Polsby 1984) and that they are keenly interested in enhancing the reputation of 
the local government as a 'totality'; that is, as a place. We further assume that the focus of administrators on reform is limited to their core interest: performing effectively within their task area; that is, the local government as an organisation (Carpenter and Krause 2012).

We begin this article by defining reputation and providing an overview of discussions of reputation reform in local councils in Norway and Denmark. We will then present our hypotheses regarding a) administrative power in the two countries, b) the size and professionalism of the local governments, and c) the actors (i.e., the different motives of politicians and administrators in reputation strategies). We then present our method, design, and empirical findings. Finally, we discuss the effects of the power structure, the size, and the actors on the reputation strategies in Norwegian and Danish local governments together with some concluding remarks.

\section{Defining reputation}

Reputation is an intangible organisational asset that can be used in the pursuit of the organisation's main goals. Reputation is defined here in terms of how stakeholders perceive an organisation's ability to create value relative to its competitors (Shapiro 1983; Weigelt and Camerer 1988). From a generic perspective on reputation, a strong reputation can increase an organisation's competitive advantage, as it may serve as a positive identification and can increase performance; and in turn, profits (Deephouse 1999; Fombrun 1996; Hall 1992; Rhee 
and Valdez 2009; Rindova et al. 2005; Shapiro 1983). From a public sector perspective, however, the aims of reputation building and management are more complex and multiple (see Wæraas and Maor 2015; Bjørnå and Salomonsen 2016). Rather than 'merely’ improving the bottom line, cultivating a favourable image relates to the varying roles of public organisations. Hence, for local governments, a favourable organisational reputation signals that a municipality is an attractive workplace and therefore able to attract and retain qualified employees and/or effectively deliver high-quality public services (Wæraas, Bjørnå, and Moldenæs 2014). A favourable reputation for a municipality as a place is likely to bring growth and further settlement, as elements such as being an attractive tourist destination, a good business environment, a good place to live (e.g. abundant recreational opportunities) will attract visitors and businesses and increase resident satisfaction (Bjørnå 2014; Braun, Eshuis, and Klijn 2014; Källström 2016). ${ }^{1}$

\section{Setting reputation in context - the cases of Norway and Denmark}

Reputation reform is a salient topic that has been very present on the political agenda in the context of local government in Denmark and Norway over the past 15 years (Salomonsen and Nielsen 2015; Wæraas and Bjørnå 2011; Wæraas, Bjørnå, and Moldenæs 2014). Table 1

\footnotetext{
${ }^{1}$ This is often referred to as 'place branding'. The terms branding and reputation management are often used interchangeably but originate in two different literatures. Both concepts engage in how organisations, states, or cities/places influence and adapt to their surroundings (Byrkjeflot, 2011).
} 
provides an overview of debates related to council reputation in recent years, reflecting how reputation has been discussed both as an individual issue and in relation to other political issues in both countries.

Table 1: Percentage of respondents reporting that reputation has been discussed as an individual topic or in relation to other political issues in the municipal council within the last two years. ${ }^{2}$

\section{[Insert Table 1 here]}

Many international comparisons have treated the Scandinavian countries as belonging to the same model of local government and following similar reform trajectories in that they are regarded as having the same type of polity and society (Bouckaert and Kuhlmann 2016; Heinelt et al. 2018). From a comparative perspective, context and culture are important factors to consider (Bouckaert and Kuhlmann 2016; Heinelt et al. 2018; Kuhlmann and Wayenberg 2016). Denmark and Norway have an intertwined historical and cultural legacy, and they both enjoy broad discretionary authority, have systems of fiscal redistribution, and have a large share of public employment and expenditures (Rose and Ståhlberg 2005). The two countries have been more or less subjected to the same reforms and trends.

Local bodies of government in Scandinavia are classified as a special type of system due to their unique administrative profile (Heinelt et al. 2018; Kuhlmann and Wollmann 2014;

\footnotetext{
${ }^{2}$ 2011-2012 in Denmark, 2013-2014 in Norway.
} 
Painter and Peters 2010). Scandinavian countries traditionally possess a highly decentralised administrative structure with politically and functionally strong local governments and a high degree of local autonomy (Bouckaert and Kuhlmann 2016; Schwab, Bouckaert, and Kuhlmann 2017). The countries differ in some respects, however, which we argue may result in differences in terms of how they perform reputation management.

\section{Hypotheses on administrative power, size, and politico-administrative differences}

Reform outcomes are assumed to differ between countries (Bouckaert and Kuhlmann 2016). Formal preconditions in countries may differ. Ways of organising local governments and size provide for differences in administrative powers and the administrative capacity to influence reputation strategies. Although Denmark and Norway are very similar, we expect there to be differences with respect to the content of reputation reform strategies. There are, after all, some political-administrative differences between the Danish and Norwegian local governments, and individual municipalities likely interpret, clarify, and adjust reputation strategies differently (see Røvik 1998).

\section{Administrative power}

The council manager form implies that all executive functions are in the hands of the chief administrative officer (CAO). This makes for powerful administrations. The committee leader 
form, on the other hand, is different. Here, the mayor is clearly the political leader of the municipality (Mouritzen and Svara 2002; Heinelt et al. 2018). This should provide for powerful politicians compared to the administration. The formal organisation of the local government apparatus in Denmark and Norway differs to some degree. Norwegian local governments are organised according to a council manager form of government. While the local government council has the general authority over policy and sets overall political targets, it is restricted from detailed involvement in administrative matters. The implementation of political decisions and administration are delegated and firmly in the hands of the CAO (Mouritzen and Svara 2002; Heinelt et al. 2018). Danish local governments are organised according to a committee leader form. The mayor may, however, not control the council. The political bodies consist of the municipal or city council, the executive committee, and a number of standing committees, which share the executive authority (Mouritzen and Svara 2002, 60). The political members of the executive committees are granted decisionmaking responsibility for the committee policy area(s). Civil servants are employed and formally supposed to act as the agents of the city council, serving the entire political board. Hence, the council manager form found in Norwegian local governments provides a formally more powerful CAO than the Danish council-manager form. We therefore expect that:

H1. Council manager governments have a greater administrative involvement in reputation-related work. 


\section{Size and professionalism}

Municipality size has relevance to our investigation, as the administrative involvement in reputation strategies likely depends on the degree of administrative competencies available for performing reputation management. Larger local governments are widely assumed to be more robust and competent (Norwegian Government White Paper 2017; Ekspertutvalgets sluttrapport 2014). Reforms since the 1990s have contributed to the differences between the two countries, which may also affect how local governments go about reputation management. Structural reform implemented in 2007 in Denmark, which included the amalgamation of smaller municipalities, has meant that Danish municipalities are now larger than those in Norway. The median population of a Danish municipality is roughly 10 times that in Norway, where as of March 2017 most municipalities had fewer than 5000 inhabitants. Local Norwegian governments are therefore comparatively smaller, have fewer staff, and are therefore predictably less professionalised than in Denmark.

Based on the assumption that larger municipalities have a more competent and robust administration, we expect that:

H2. The bigger the municipality (size), the greater the administrative involvement in reputation-related work.

\section{Reputation management and the political-administrative relationship}


The municipal leadership consists of politicians and administrators. They have different responsibilities and tasks. As 'where you stand depends on where you sit' (Allison 1969, 711), politicians and administrators are likely to have different roles, interests, and targets for their reputation strategies (Bjørnå 2016; Wæraas, Moldenæs, and Bjørnå 2014). They want to create a flourishing business environment, attract more taxpayers, and boost tourism, as such elements are assets in the political 'game' (Bjørnå and Aarsæther 2010; Polsby 1984). The political actors are likely to focus on the municipality as a place for business settlement, a good place to live, and a tourist destination (Kotler, Haider, and Rein 1993; Papadopoulos 2004; Salomonsen and Nielsen 2015; Wæraas, Bjørnå, and Moldenæs 2014). In order to uphold and gain support (and thereby positions), politicians must be attentive to interests in their constituency. They need to prioritise interests and develop political positions vis-à-vis other political parties. While disagreement and debate are part of the political raison d'être (Grøn and Salomonsen 2018; Korsiara-Pedersen and Pedersen 2013), this is not easily compatible with the core ideas in reputation management: reputation management theories emphasise the need for consistency regarding an organisation's core values, identity, and strategy. According to theories about reputation, it is crucial to ensure loyalty to a reputationrelated project and to communicate this loyalty externally (Fombrun and van Riel 2004; Schultz, Antorini, and Csaba 2005). The debates and disagreement we find as part of the political raison d'être do not 'fit in'. It is plausible to assume that 'communicating with one voice' poses a problem; political disagreement about interests, values, and reputation 
strategies is likely. This has been referred to in the reputation literature as the "politics problem' (Wæraas and Byrkjeflot 2012, 193). According to this line of reasoning, the political forging of a place reputation is a difficult endeavour.

Compared to the politicians, the administration is in a simpler situation; it is expected to work in agreement and to have clear goals. For administrative actors, a good reputation as a service provider, which also includes attracting qualified employees, is a valuable resource (Carpenter and Krause 2012; Salomonsen and Nielsen 2015; Wæraas, Bjørnå, and Moldenæs 2014); it can increase public support and may also lead to additional delegated autonomy (Carpenter 2010; Maor 2010). The administrative leadership is likely to target what they are responsible for in reputation strategies: the organisational reputation of the local government. The larger and stronger the administrative unit, the greater the probability that there will be organisational reputation strategies.

Due to the contrasting interests of the political and administrative actors described above, we expect that:

H3. The greater the administrative involvement in reputation work, the higher the priority regarding the municipality's reputation as a good organisation.

\section{Method and design}


The analyses here are based on two surveys. The Norwegian survey was sent to all of the mayors and CAOs in Norway in 2015. The Danish survey was sent to all of the mayors of the 98 Danish local governments and to the CAOs and persons responsible for strategic communications in 2013. Both surveys used 5-point Likert scales for the questions of interest to this study.

Both survey designs make it possible for more than one individual to provide information about the municipality's reputation strategy and the involvement of different actors. Because we are interested in the municipality's reputation strategy and the actors involved (and not the individual responses, as such), we wanted one score per municipality per question. To achieve this, we used the average response of the respondents within each municipality.

The variable representing the involvement of the administration is the average score of the following actors: the $\mathrm{CAO},{ }^{3}$ the administration/remaining members of the administration, ${ }^{4}$ the Head of Communications, ${ }^{5}$ and the employees/other employees. ${ }^{6}$ The variable representing the involvement of political actors is the average score of the mayor ${ }^{7}$ and the remaining members of the municipal/city council. ${ }^{8}$

\footnotetext{
3 'Rådmann/Kommunaldirektør'.

4 'Adm/øvrige medl av administrasjonen'.

5 'Kommunikasjonsansvarlig'.

6 'Ansatte/andre medarbeidere'.

7 'ordfører/borgermester'.

8 'kommunestyret/øverige byrådmedlemmer'.
} 
To account for municipality size, we used a logarithm of the population. Log transformation usually makes sense when the variable only has positive values and the relative variation is high (Gelman and Hill 2007).

To investigate the local governments' reputation strategies, we created two scales inspired by Wæraas, Bjørnå, and Moldenæs (2014): one for place reputation and one for organisational reputation. The standardised Cronbach's alphas for the scales ${ }^{9}$ lie within the range of values usually considered acceptable when Cronbach's alpha is used as a reliability measure (Tavakol and Dennick 2011). We should note that the division between place and organisational reputation is more of an analytical tool than a de facto choice and that the choice of what to target and which strategies to use is likely affected by pragmatic considerations (Wæraas, Bjørnå, and Moldenæs 2014).

After creating these scales, we calculated the difference between the two scores, which was used as the dependent variable in the investigation of $\mathrm{H} 3$; the higher the value of this variable, the more favoured are the organisational strategies. This allowed us to investigate the relative importance of the strategies. It is worth noting that there is no natural dichotomy between them, and it is therefore possible that both strategies are important in a municipality.

${ }^{9}$ Place Denmark: 0.67, Organisation Denmark: 0.74, Place Norway: 0.88, Organisation Norway: 0.88 . 
The questions regarding the items in the scales were posed slightly differently in the two surveys. The Danish questions addressed the purpose (formål) of the reputation work, whereas the Norwegian questions focused on the importance of certain goals in the reputation work.

If the scales measured the same concept, we would expect the changes in the scales to occur more or less in unison. For example, if the Norwegian scale is increasing, we would also expect an increase if the Danish scale had been used. Thus, if we ignore the differences in level and focus on the changes in these scales, we should be able to use the scales meaningfully despite the slightly different phrasing of the underlying questions.

\section{Actors involved and reputation strategy in Denmark and Norway}

The table below displays the numbers of valid observations, the means, the medians, and the minimum and maximum values of the variables used in this article. The population variable is not used, but it is included to highlight the variation in municipality size on an easily understandable scale. The Danish local governments tend to favour a place-reputation strategy over an organisational strategy $(-0.49)$, while their Norwegian counterparts slightly favour an organisational strategy $(0.03)$. This could be due to the fact that the items used in the scales are slightly different or could be due to real differences in the preference of strategies. This uncertainty is why we controlled for the level differences between the countries when investigating their reputation strategies. 
Table 2: Summary statistics

\section{[Insert Table 2 here]}

The correlation matrix of the variables considered is presented below. The correlations between the variables are quite low; hence, we avoid problems with multicollinearity. The highest correlation is found between the involvement of the CAO and that of the administration (0.62). This is hardly surprising, as the CAO is also included in the administration variable.

Table 3: Correlation matrix

\section{[Insert Table 3 here]}

\section{Empirical findings}

In this section, we address the hypotheses through statistical models. The hypotheses are reiterated, and the models are shown and discussed. We start with the first hypothesis.

\section{H1: Council manager governments have a greater administrative involvement in} reputation work.

Given that Norwegian CAOs enjoy a more prominent position than their Danish colleagues, we expect Norwegian local governments to have a greater administrative involvement in reputation work. This hypothesis was tested with a regression with the scale of the different actors as the dependent variable and using a dummy variable to separate the Danish and 
Norwegian municipalities. Norwegian municipalities have the value of 1 on the dummy variable, while the Danish municipalities have value 0 . The coefficient is thus the difference in the mean involvement of the group of actors between the Norwegian and Danish municipalities.

Table 4: Involvement of administrative and political actors in Norway and Denmark

\section{[Insert Table 4 here]}

As the first model in Table 4 shows, there is a difference between the involvement of the administration in reputation work in Norwegian and Danish municipalities. The administration is generally less involved in the Norwegian municipalities than in Denmark. There is no difference in the involvement of the CAOs (model 2 in Table 4), and the political actors (model 3 in Table 4) are slightly more involved in Norway, although the difference is not significant.

H2: Given that the administration in larger local governments is more professional, we expect that the larger the municipality (size), the greater the administrative involvement in reputation work.

As when testing $\mathrm{H} 1$, we ran a regression wherein the dependent variable was the average score of the involvement of the actors in question. We used the logarithm of the size of the municipality's population and a country dummy as explanatory variables. 
Table 5: Municipality size and the involvement of the administration, the CAO, and political actors.

\section{[Insert Table 5 here]}

As illustrated in model 4 in Table 5, there is a positive and significant relationship between municipality size and the involvement of the administration. This tells us that the larger the municipality, the more involved the administration is in the reputation work. We can also see that when adding size as a variable, country differences are no longer significant. This indicates that some of the differences observed were due to the fact that Norwegian municipalities are generally smaller than their Danish counterparts. When it comes to the relationship between political actors and municipality size, the opposite relationship is found; the larger the municipality, the less the involvement of political actors in reputation work. Again, we see that the country effect is no longer significant, indicating that the size of the municipality acted as a confounding factor here as well.

H3: The greater the administrative involvement in reputation work, the higher the priority will be on a reputation of the municipality as a good organisation.

To test the involvement hypothesis, we calculated the difference between the organisational reputation score and the place reputation score. This left us with the dependent variable, where values greater than 0 indicate that organisational reputation strategies are more 
important than place reputation strategies. In contrast, values less than 0 indicate that organisational reputation strategies are less important than place reputation strategies. We included the country dummy to control for any level differences between the countries.

Table 6: Regression of the differences between organisational reputation and place reputation. Larger dependent-variable values represent a higher score on organisation (as opposed to place).

\section{[Insert Table 6 here]}

The models in Table 6 display the relationships between the relative importance of the reputation related to the organisation as opposed to the reputation stemming from the municipality as a place and the size of the municipality, the involvement of the administration, and the involvement of political actors. The models also include a dummy variable for country to control for country-level differences.

We find a significant and positive relationship between the involvement of the administration and the degree to which the municipality favours its reputation as an organisation rather than as a place. This means that if the involvement of political actors remains the same and the involvement of the administration increases, the municipality tends to choose reputation strategies aimed more at promoting the municipality as a good organisation and to a lesser degree as a good place to live. There is a negative relationship between the involvement of 
political actors and the degree to which the municipality favours the reputation of the organisation. However, it is not significant.

Models 9 and 10 test whether there are any differences in the involvement of the actors and the degree to which organisational reputation strategies are favoured in Norwegian and Danish municipalities. Model 9 (Table 6) shows that the positive relationship between the involvement of the administration and the favouring of an organisational strategy in Denmark is slightly stronger than in Norway. ${ }^{10}$ However, this difference is not significant. With respect to the involvement of political actors (model 10 in Table 6), the relationship is slightly positive in Denmark and negative in Norway, ${ }^{11}$ which means that more politicians involved in Norway leads to less organisational focus in reputation strategies. However, none of these findings are significant. There does not appear to be enough evidence to conclude that there are any reputation-related response differences between the two countries.

\section{Discussion}

In this article, our aim was to explore municipal reputation reform management as a response to the call for research identifying crucial conditions for when and how organisations pursue reputation reform strategies. We have investigated three such conditions: We have tested, in a

\footnotetext{
${ }^{10}$ Denmark: 0.243 , Norway: $0.243-0.039=0.204$

${ }^{11}$ Denmark: 0.026, Norway: $0.026-0.124=-0.098$.
} 
comparative research design, the effects of the power structure, the size, and the actors involved in Danish and Norwegian local government reputation strategies.

\section{Administrative power and involvement in reputation strategies}

The CAOs in Norway have (at least formally) a more prominent position than their Danish colleagues. Therefore, we expected the Norwegian administration's involvement in reputation work to be of greater significance than that of its Danish counterparts. The results do not confirm this hypothesis; rather, they contradict it: The administration in Norwegian local government is significantly less involved than in Denmark.

The contradiction of Hypothesis 1 can be explained using the information presented in Table 1. Here, we see that it is more common in Norway to discuss municipal reputation in relation to other topics on the agenda, whereas in Denmark it is common to bring it up as an issue unto itself. This indicates that reputation strategies have been treated as a more comprehensive strategy for Danish municipalities and that reputation reforms are more integrated in different task areas in Norway. An integrative approach, again, is likely to involve political deliberations and debate and to downplay administrative influence. An explanation for why the administration in Norwegian local government is less involved in reform strategies than is the case in Denmark is likely to be found in the fact that reputation reform processes have been different; this reform has been interpreted, clarified, and adjusted differently in the different countries (see Røvik 1998; Kuhlmann and Wayenberg 2016). How reputation reform 
is implemented matters, as how things are done has implications for the scope of group involvement and influence in discussions. The contradiction of the hypothesis could also be interpreted as indication that a) the countries' local administrative powers are more similar in practice than they are formally, and/or b) administrative powers have little influence in determining reputation strategies.

\section{The effect of the size of local governments and the degree of professionalism}

Due to differences in their reform history, Danish local governments are distinctly larger than those in Norway in population (i.e. in size). This enable us to study the next hypothesis, which addresses size and professionalism: We expected that the bigger the municipality, the greater would be the administrative involvement in reputation strategies $(\mathrm{H} 2)$. We found the involvement of administrators in reputation-related work to be greater in larger local governments. We also found that the counter-intuitive results from the foregoing hypothesis lost their significance: When controlling for size, the degree of administrative involvement in reputation work in the two countries is quite similar.

This is an interesting finding regarding the role of local government administrators in both Denmark and Norway: The administrative influence on reputation strategies increases with size. Its increased influence is likely due to the complexity in larger local government and the corresponding need for greater technical skills and specialisation. The expansion of welfare 
tasks renders it necessary for the administration to be more professional and to execute more tasks. This has led to efforts to enhance political initiatives in alternative ways. New Public Management (NPM) measures, including 'management by objectives' (MBO) and strategic political management, have been introduced in all of the Scandinavian countries (Kleven et al. 2000). Such changes involve the delegation of responsibility from the political bodies to a professional administration. According to Stocker and Thompson-Fawcett (2014), the resulting complexity will make it more difficult for politicians to participate in the strategyformation process, which partially explains the increasing administrative influence on reputation strategies with increasing size.

The increasing administrative influence on reputation strategies with size can also be seen as a result of local government communication departments. Most large local governments have such departments, and it is reasonable to assume that the actors comprising them contribute to reputation processes (Salomonsen and Nielsen 2015). A more professional administration with a department with expertise in issues related to communication and reputation is more likely to excel in work on reputation strategies.

\section{The actors in reputation management}

We find a significant, positive relationship between administrative involvement and organisational reputation strategies. Greater administrative involvement steers the reputation 
strategy towards organisational reputation, which moves the reputation strategies towards ends that are most advantageous for administrative motives and interests (see Allison 1971; Carpenter 2001; Carpenter and Krause 2012; Peters 2001; Svara 2006). The more the administration is involved, the greater the focus on improving the quality of the municipality's services and attracting qualified employees. These findings are in line with expectations that political and administrative actors will focus on their core activity in their formation of reputation strategies (Bjørnå 2014; Wæraas, Bjørnå, and Moldenæs 2014).

\section{The Norwegian and Danish engagement in reputation reform}

Contrary to what may be expected - that local government reform outcomes differ between countries (Bouckaert and Kuhlmann 2016) - we find that (when controlled for the size of the municipality) the local governments in the two countries capture the trend similarly and follow the same trajectories when working with reputation and brand strategies. Both countries are tuned to organisational reputation strategies; country-specific factors have no significant impact on reputation strategy content. The most likely explanation for this is the tendency organisations have to copy one another and to use the same sort of templates in such reform practises, both across and within countries (DiMaggio and Powell 1991). The classical strife and tension between politicians and administrators is less prevalent in the reputation policy field (Salomonsen and Nielsen 2015), perhaps due to core reputation-related ideas such as consistency and a common identity. In such processes, differences and conflicts must be 
deemphasised and there is a common interest in good organisational performance and increased citizen satisfaction (see Van Ryzin 2007). Previous research on reputation work in Denmark and Norway shows that politicians and administrators do not differ much in worldviews and often work together when working on municipal reputation, pulling from their respective strengths (Salomonsen and Nielsen 2015; Aarsæther and Bjørnå 2017).

However, our findings also reveal that municipal administrators play a prominent role in forming reputation strategies in both countries. Although the countries included in this study differ in some respects, their polities and societies are very similar and are part of the Scandinavian administrative tradition (Bouckaert and Kuhlmann 2016; Heinelt et al. 2018; Painter and Peters 2010), which seems to allocate a rather prominent role to the local administration in large local governments. The growth of municipal communication departments with an interest in reputation strategies has also furthered the administrative foothold in reputation strategy processes (Salomonsen and Nielsen 2015). And as the roles of the actors engaged in forming such reputation strategies are linked to the direction that the strategy takes, the similarity in reform response might also be explained rationally by administrative dominance and interests in reputation strategy formation (see Carpenter 2001; 2010).

This article is positioned between two strands of Scandinavian research regarding local government reputation management. We have examined the role and influence of major local 
government actors in reputation management (Bjørnå 2014, 2016; Salomonsen and Nielsen 2015) and how local governments respond to a strategy originating in the private sector and the challenges that reputation management poses for the public sector (Frandsen, Johansen, and Salomonsen 2016; Luoma-aho 2007; Wæraas and Byrkjeflot 2012). While major contributors to the public reputation literature such as Carpenter $(2001,2010)$ have focused on governmental agencies, where the political level is more distant, we have focused on democracies. Administrative involvement in the formulation of reform policies, at least when it comes to reputation reform, increases with local government size. In reputation reform strategies, administrators in large local governments have more influence than do politicians on reputation strategy content. In a local democracy, this is problematic: Reputation reforms involve core municipal values and decisions with political impact. In a democracy, politicians cannot be excluded from reform processes that involve service provision and political goals (Bouckaert and Kuhlmann 2016; Schwab, Bouckaert, and Kuhlmann 2017), and in a democracy, politicians bear the ultimate responsibility and are accountable for the reform goals pursued and resources spent. Democracy suffers when administrative power increases vis-à-vis the political sphere. This seems to be the issue with increasing local government size, at least when local governments are pursuing reputation-reform policies.

The article demonstrates that comparative studies of reform processes in countries with rather similar government structures have the potential to further our understanding of reform impacts. It also demonstrates the relevance of the rational perspective and agency as an 
explanatory component for reform outcomes: It demonstrates that in local democratic organisations, politicians and administrators play different roles and have different interests and targets for their reputation-reform strategies.

\section{Conclusion}

Our aim in this article was to explore municipal reputation reform management and the relevance of agency (i.e. a purposeful way of managing reputation as opposed to imitation) in such reforms. This as a response to the call for research identifying crucial conditions for when and how organisations pursue their reputation reform strategies. We find that local governments respond differently in reputation-reform processes depending on the actors involved and municipal size. In local governments, the degree of political and administrative involvement matters for reputation-reform strategy content as the actor groups may have diverging interests.

Contrary to what one might expect (Bouckaert and Kuhlmann 2016), we found countryspecific factors to have less impact on reputation strategy content. This can be explained by the fact that local governments, like other organisations, capture trends and reforms in a similar way to demonstrate that they are 'up to date' (DiMaggio and Powell 1991) as well as the major similarities in the formal structure, roles, and interests. The local government administration plays a prominent role in both systems (Bouckaert and Kuhlmann 2016; 
Heinelt et al. 2018; Painter and Peters 2010; Salomonsen and Nielsen 2015) and is likely to spend much time cultivating a reputation that will allow them to increase bureaucratic autonomy (Carpenter and Krause 2012).

This article is an attempt to provide systematic research within the limits of the available data. We encourage future research to investigate whether our findings hold when other factors are considered. Two interesting factors to explore further could be the effect of 1) the existence and size of a municipal communication division and 2) the financial situation in the municipalities.

Lastly, we would like to encourage the study of local government reputation reform strategies and the actors involved in other national contexts beyond the Scandinavian habitat. Whereas country differences may prove important in other studies, ours further point to the relevance of drawing comparisons between local governments which differ on less political but more organisational aspects, such as size. 


\section{References}

Aarsæther, N., and H. Bjørnå. 2017. "Skjønnskomponenten i utøvelse av kommunal ledelse." In Ledelse og skjønnsutøvelse: Analyse, intuisjon, forhandlinger, edited by O. J. Andersen, T. Moldenæs, and H. Torsteinsen, 156-176. Bergen: Fagbokforlaget.

Allison, G. T. 1969. "Conceptual Models and the Cuban Missile Crisis." The American Political Science Review 63 (3): 689-718.

Allison, G. T. 1971. Essence of Decisions: Explaining the Cuban Missile Crisis. Boston: Little Brown.

Bjørnå, H. 2014. "Omdømmebygging i kommunene - hva gjør de og hva vil de?" Norsk statsvitenskapelig tidsskrift 4: 256-276.

Bjørnå, H. 2016. "Norwegian Municipalities and Reputation Building: Agents, Agendas, Colaitions and Outcomes." Scandinavian Journal of Public Administration 20 (2): 39-58.

Bjørnå, H., and N. Aarsæther. 2010. "Networking for Development in the North: Power, Trust, and Local Democracy." Environment and Planning C: Government and Policy 28 (2): 304-317.

Bjørnå, H., and H. H. Salomonsen. 2016. "Reputation and Brand Management in Scandinavian Municipalities." Scandinavian Journal of Public Administration 20 (2): 3-5.

Bouckaert, G., and S. Kuhlmann. 2016. "Introduction: Comparing Local Public Sector Reforms: Institutional Policies in Context." In Local Public Sector Reforms in Times of Crisis: National Trajectories and International Comparisons, edited by S. Kuhlmann and G. Bouckaert. Basingstoke: Palgrave Macmillan.

Braun, E., J. Eshuis, and E. H. Klijn. 2014. "The Effectiveness of Place Brand Communication." Cities 41: 64-70.

Byrkjeflot, H. 2011. “Et kritisk blikk på omdømmeblikket." In Substans og framtreden: Omdømmehåndtering i offentlig sektor, edited by A. Wæraas, H. Byrkjeflot and S. I. Angell, 51-70. Oslo: Universitetsforlaget.

Carpenter, D. 2001. The Forging of Bureaucratic Autonomy: Reputations, Networks and Policy Innovation in Executive Agencies, 1862-1928. Princeton: Princeton University press.

Carpenter, D. P. 2010. Reputation and Power: Organizational Image and Pharmaceutical Regulation at the FDA. Princeton: Princeton University Press.

Carpenter, D. P., and G. A. Krause. 2012. "Reputation and Public Administration." Public Administration Review 72 (1): 26-32.

Christensen, T., M. Egeberg, H. O. Larsen, P. Lægreid, and P. G. Roness. 2002. Forvaltning og politikk. Oslo: Universitetsforlaget.

Deephouse, D. L. 1999. "To Be Different, or to Be the Same? It's a Question (and Theory) of Strategic Balance." Strategic Management Journal 20 (2): 147-166.

DiMaggio, P. J., and W. W. Powell. 1991. "The Iron Cage Revisited: Institutional Isomorphism and Collective Rationality in Organizational Fields." In The New Institutionalism in Organizational Analysis, edited by W. W. Powell and P. J. DiMaggio. Chicago: University of Chicago Press. 
Ekspertutvalgets sluttrapport. 2014. Kriterier for god kommunestruktur. Retrieved from: https://www.regjeringen.no/globalassets/upload/kmd/komm/rapporter/kriterier for god k ommunestruktur sluttrapport.pdf.

Fombrun, C. 1996. Reputation: Realizing Value from the Corporate Image. Boston, MA: Harvard Business School Press.

Fombrun, C. J., and C. B. M. van Riel. 2004. Fame and Fortune: How Successful Companies Build Winning Reputations. Upper Saddle River, N.J.: Prentice Hall.

Frandsen, F., W. Johansen, and H. H. Salomonsen. 2016. "Responding to Institutional Complexity: Reputation and Crisis Management in Danish Municipalities." Scandinavian Journal of Public Administration 20 (2): 7-36.

Gelman, A., and J. Hill. 2007. Data Analysis Using Regression and Multilevel/Hierarchical Models. New York, NY: Cambridge University Press.

Government White Paper. 2017. Kommunereform. Retrieved from: https://www.regjeringen.no/no/tema/kommuner-ogregioner/kommunereform/kommunereform/id2548377/.

Grøn, C. H., and H. H. Salomonsen. 2018. "Political Instability and the Ability of Local Government to Respond to Reputational Threats in Unison." International Review of Administrative Science Online before print. doi: 10.1177/0020852317714533.

Hall, R. 1992. "The Strategic Analysis of Intangible Resources." Strategic Management Journal 13 (2): 135-144.

Heinelt, H., N. Hlepas, S. Kuhlmann, and P. Swianiewicz. 2018. "Local Government Systems: Grasping the Institutional Environment of Mayors." In Political Leaders and Changing Local Democracy: The European Mayor, edited by H. Heinelt, A. Magnier, M. Cabria and H. Reynaert, 19-79. Houndmills: Palgrave Macmillan.

Jacobsen, K. D. 1960. "Lojalitet, nøytralitet og faglig uavhengighet i sentraladministrasjonen." Tidsskrift for samfunnsforskning 1 (1): 231-248.

Kleven, T., T. S. Floris, M. Granberg, S. Montin, O. Rieper, and S. I. Valo. 2000. "Renewal of Local Government in Scandinavia: Effects for Local Politicians." Local Government Studies 26 (2): 93-116. doi: 10.1080/03003930008433991.

Korsiara-Pedersen, K., and H. H. Pedersen. 2013. "Partier og partisystemer." In Det demokratiske system, edited by J. G. Christensen and J. Elklit. Copenhagen: Hans Reitzels.

Kotler, P., D. H. Haider, and I. Rein. 1993. Marketing Places: Attracting Investment, Industry, and Tourism to Cities, States and Nations. New York: Cambridge University Press.

Kuhlmann, S., and E. Wayenberg. 2016. "Institutional Impact Assessment in Multi-Level Systems: Conceptualizing Decentralization Effects from a Comparative Perspective." International Review of Administrative Sciences 82 (2): 233-254. doi: 10.1177/0020852315583194.

Kuhlmann, S., and H. Wollmann. 2014. Introduction to Comparative Public Administration: Administrative Systems and Reforms in Europe. Northampton: Edward Elgar.

Källström, L. 2016. "Rethinking the Branding Context for Municipalities." Scandinavian Journal of Public Administration 20 (2): 77-95. 
Luoma-aho, V. 2007. "Neutral Reputation and Public Sector Organizations." Corporate Reputation Review 10 (2): 124-143.

Maor, M. 2010. "Organizational Reputation and Jurisdictional Claims: The Case of the US Food and Drug Administration." Governance 23 (1): 133-159.

Mouritzen, P. E., and J. H. Svara. 2002. Leadership at the Apex: Politicians and Administrators in Western Local Governments. Pittsburg, PA: University of Pittsburgh Press.

Painter, M., and B. G. Peters. 2010. Tradition and Public Administration. Basingstoke: Palgrave Macmillan.

Papadopoulos, N. 2004. "Place Branding: Evolution, Meaning and Implications." Place Branding 1 (1): 36-49.

Peters, B. G. 2001. The Politics of Bureaucracy: An Introduction to Comparative Public Administration $5^{\text {th }}$ ed. London: Routledge.

Polsby, N. W. 1984. Political Innovation in America: The Politics of Policy Initiation. New Haven, CT: Yale University Press.

Rhee, M., and M. E. Valdez. 2009. "Contextual Factors Surrounding Reputation Damage with Potential Implications for Reputation Repair." Academy of Management Review 34 (1): 146168.

Rindova, V. P., I. O. Williamson, A. P. Petkova, and J. M. Sever. 2005. "Being Good or Being Known: An Empirical Examination of the Dimensions, Antecedents, and Consequences of Organizational Reputation." Academy of Management Journal 48 (6): 1033-1049.

Rose, L. E., and K. Ståhlberg. 2005. "The Nordic Countries: Still the Promised Land?" In Comparing Local Governance: Trends and Developments, edited by B. Denters and L. E. Rose. Houndsmill: Palgrave.

Røvik, K. A. 1998. Moderne organisasjoner: Trender i organisasjonstenkningen ved årtusenskiftet. Bergen: Fagbokforlaget.

Salomonsen, H. H., and J. A. Nielsen. 2015. "Investigating the Politics of Reputation Management in Local Government: The Case of Denmark." In Organizational Reputation in the Public Sector, edited by A. Wæraas and M. Maor. New York, NY: Routledge.

Schultz, M., Y. M. Antorini, and F. F. Csaba. 2005. Corporate Branding: Purpose, People, Process. Copenhagen: Copenhagen Business School Press.

Schwab, C., G. Bouckaert, and S. Kuhlmann. 2017. The Future of Local Government in Europe: Lessons from Research and Practice in 31 Countries. Berlin: Nomos/Ed. Sigma.

Shapiro, C. 1983. "Premiums for High Quality Products as Returns to Reputations." The Quarterly Journal of Economics: 659-679.

Stocker, N., and M. Thompson-Fawcett. 2014. "'It's Not Like Never-the-Twain-Shall-Meet': PoliticianStaff Relationship Structures in Local Government." Local Government Studies 40 (5): 791808.

Svara, P. H. 2006. "The Search for Meaning in Political-Administrative Relations in Local Government." International Journal of Public Administration 29 (12): 1065-1090.

Tavakol, M., and R. Dennick. 2011. "Making Sense of Cronbach's Alpha." International Journal of Medical Education 2:53-55. 
Van Ryzin, G. G. 2007. "Pieces of a Puzzle: Linking Government Performance, Citizen Satisfaction, and Trust." Public Performance \& Management Review 30 (4): 521-535.

Weigelt, K., and C. Camerer. 1988. "Reputation and Corporate Strategy: A Review of Recent Theory and Applications." Strategic Management Journal 9 (5): 443-454. doi: 10.1002/smj.4250090505.

Wæraas, A., and H. Bjørnå. 2011. "Kommunegrå eller unik? Omdømmehåndtering i kommunesektoren." In Substans og framtreden: Omdømmehåndtering i offentlig sektor, edited by A. Wæraas, Haldor Byrkjeflot and Svein Ivar Angell, 230-245. Oslo: Universitetsforlaget

Wæraas, A., H. Bjørnå, and T. Moldenæs. 2014. "Place, Organization, Democracy: Three Strategies for Municipal Branding." Public Management Review. doi: 10.1080/14719037.2014.906965.

Wæraas, Arild, and Haldor Byrkjeflot. 2012. "Public Sector Organizations and Reputation Management: Five Problems." International Public Management Journal 15 (2): 186-206. doi: 10.1080/10967494.2012.702590.

Wæraas, Arild, and Moshe Maor. 2015. Organizational Reputation in the Public Sector. New York, NY: Routledge. 